\title{
LOCALIZATION OF A CUTICULAR PROTEIN DURING THE POSTEMBRYONAL DEVELOPMENT OF MANDUCA SEXTA*
}

\author{
Gy. Csikós, ${ }^{* *}$ Kinga MolnÁR, NoÉmi H. BorHegYi and M. SASS \\ Department of General Zoology, Eötvös Loránd University, P.O. Box 330, H-1445 Budapest, Hungary
}

(Received: January 10, 2001; accepted: March 2, 2001)

\begin{abstract}
The pattern of cuticle protein synthesis by the epidermis of insects changes during the last larval, pupal and adult development, leading to an alteration in cuticular stucture and feature. We have isolated a protein that had an apparent molecular mass of $33.1 \mathrm{kD}$ from larval cuticle of Manduca sexta. Synthesis, transport and accumulation of MsCP33.1 were followed during metamorphosis by immunoblots and immunocytochemical methods using the antibody developed against this protein. Our data prove that the presence of MsCP33.1 in the larval cuticle is general while its appearance in the pupal or adult integument is restricted only in the cuticle of wings and apodemes. We established that the synthesis of 33.1 $\mathrm{kD}$ protein is negatively regulated by moulting hormone (20-hydroxyecdysone). Possible roles for this cuticular protein are discussed.
\end{abstract}

Keywords: Cuticular protein - immunolocalization - moulting hormone - metamorphosis

\section{INTRODUCTION}

Insect cuticule is an extracellular structure that is composed largely of two classes of macromolecules: carbohydrate and protein. Chitin filaments composed of $\mathrm{N}$-acetylglucosamine chains are likely involved in the basic arhitecture of the cuticle. Chitins may vary somewhat in chain length and degree of acetylation but the observed differences of chitins of various species or during the developmental stages are minor. The particular protein components may show a specific spatial and/or temporal distribution in the larval, pupal or imaginal cuticle. Proteins belong to the first group exercise influence over the mechanical properties of the cuticle (i.e. soft, flexible or hard, rigid cuticle), while the members of the second group are the stage-specific proteins.

Morphogenesis which manifests also in development of extracellular structures depends on a changing pattern of protein synthesis by the cells responsible to secrete them. Cuticular proteins might have characteristic localizations through the

\footnotetext{
*Dedicated to Professor János Kovács on the occasion of his 70th birthday.

**Corresponding author; e-mail: gcsikos@cerberus.elte.hu
} 
body/segment parts [9], [6, 22, 44]. It may be important that some cuticular proteins occur not only in integumental cuticle, but in tracheal cuticle, too [10, 32].

The aim of our work is to follow the synthesis, secretion, transport and accumulation of several cuticle proteins in Manduca sexta by immunoblots and immunocytochemical methods during the last larval and pupal stages. Our results up till now show that different groups of cuticular protein can be distinguished. One group of the cuticle proteins is synthesized in the epidermis and secreted apically into the larval cuticle and decomposed during the moulting process. A second group of proteins of the integumental cuticle are synthesized in the fat body and transported into the integument. Other proteins are transported from the cuticle back to the hemolymph and stored in the fat body before the ecdysis, or reappeare in the pupal cuticle again [10].

Now we report a recently characterized cuticular protein which possesses molecular mass of $33.1 \mathrm{kD}$ which has a special pattern regarding both of synthesis and localization during the postembryonal development.

\section{MATERIALS AND METHODS}

\section{Experimental animals}

Tobacco hornworm (Manduca sexta) eggs were kindly provided by Prof. S. E. Reynolds (Univ. of Bath). Larvae were reared according to his instructions based on the techniques of Bell and Joachim [3], on a wheat germ based artificial diet, at 25 ${ }^{\circ} \mathrm{C}, 17 \mathrm{~L}$ : 7D photoperiod and $60 \%$ relative humidity. Animals were selected that ecdysed to the fifth instar between 22.00 and 02.00 AZT (Arbitrary Zeitgeber Time). Different stages of development were recognised by a staging scheme adapted from Samuels and Reynolds [30].

\section{Sample preparation. Hemolymph}

Samples were collected by puncturing of prolegs and drops of it were allowed to drip onto crystals of phenylthiourea in an Eppendorf tube. Samples were centrifuged for $5 \mathrm{~min}$ at $3000 \mathrm{~g}$ to pellet the haemocytes. The supernatant was diluted twice its volume of homogenisation buffer which contained $100 \mathrm{mM}$ sucrose, $1 \%$ dextran, 40 $\mathrm{mM}$ Tris maleate ( $\mathrm{pH}$ 7.2), $0.5 \mathrm{mM} \mathrm{MgCl} 2,100 \mathrm{mM} \mathrm{KCl}, 10 \mathrm{mM} \mathrm{NaCl}, 5.0 \mathrm{mM}$ mercapto-ethanol and $10 \mathrm{mM}$ PMSF. Epidermis. Last segment of caterpillar was cut off and the carcass was placed on a glass surface between parallel strips of sticky tape. A test tube rolled from head to tail caused internal organs to be extruded from the cut end. The integument skin was washed and epidermis squeezed out by rolling with more pressure and no clearance of tapes. Epidermal cell layer was collected in $100 \mu \mathrm{l}$ of homogenisation buffer. Samples were observed under stereomicroscope for possible undesired contamination with cuticle or muscles. Cuticle. Integumental 
sheet was rolled out till stereomicroscope observation showed no longer contained epidermis. Pure cuticle was cut into small pieces and collected in an Eppendorf tube containing $200 \mu \mathrm{l}$ of homogenisation buffer. Internal organs. Fat body lobes, salivary glands, midgut, gonads, tracheae were removed from dissected caterpillars as quick as it was possible. They were rinsed in a large volume of ice cold homogenisation buffer and all contaminating tissues were very carefully removed under a stereomicroscope. Tissue samples were quickly blotted and collected in 50 , or $100 \mu \mathrm{l}$ of homogenisation buffer.

Samples were homogenized in a glass-teflon homogenizer and the debris was removed by a short centrifugation. Freshly prepared samples were boiled for $3 \mathrm{~min}$ with equal volume of SDS sample buffer [20].

\section{Analytical gel-electrophoresis}

SDS-PAGE was carried out according to the method of Laemmli [20] on a $10 \%$ separating gel overlaid with a $3 \%$ stacking gel in a BioRad Minigel chamber. Gels were usually stained with Coomassie BBR to visualize the peptides. Molecular mass of the peptides was determined by coelectrophoresis with standards from the Bio-Rad broad molecular weight calibration kit.

\section{Protein purification}

Cuticle peptides were separated on $10 \%$ polyacrylamide gel, respectively, in a BioRad Prep Cell (Model 491) chamber. Peptides were run for overnight at $10^{\circ} \mathrm{C}, 100$ $\mathrm{mA}$ and then they were eluted from the gel column at $120 \mathrm{~mA}$. Volume of collected fractions was $1.5 \mathrm{ml}$. Fractions were dialysed overnight against distilled water at $4{ }^{\circ} \mathrm{C}$ and concentrated in a SpeedVac system (RC10-10, Jouan). Purity of individual fractions was tested by analytical gel electrophoresis and the fractions containing the same peptides in an electrophoretically pure form were pooled and stored at $-70{ }^{\circ} \mathrm{C}$ until the use.

\section{Antibody development}

C57/Black mice were immunised with 25-30 $\mu \mathrm{g}$ of isolated and electrophoretically pure peptides, dissolved in $100 \mu \mathrm{l}$ of PBS and emulsified with $100 \mu \mathrm{l}$ of Freund's complete adjuvant. Animals were boosted 3 weeks later with the same amount of peptides dissolved in $100 \mu \mathrm{l}$ of PBS and mixed with $100 \mu \mathrm{l}$ of Freund's incomplete adjuvant. Titer of the antibodies was tested in blood samples collected from the tip of the tail. After completion of immunisation the mice were bled and the IgG fraction was separated from the serum by ammonium sulphate precipitation. 


\section{Immunoblotting}

Peptides were electrophoreticaly transferred to a sheet of nitrocellulose (Bio-Rad, 0.2 $\mathrm{m}$ pore size) according to the method of Towbin et al. [38], in a Bio-Rad MiniBlot chamber. Nonspecific binding sites of nitrocellulose sheet were blocked by $5 \%$ Carnation non-fat dry milk powder in TRIS buffer $(0.15 \mathrm{M}$ TRIS, $0.5 \mathrm{M} \mathrm{NaCl}, \mathrm{pH}$ 7.0). After washing three times with TBS, sheets were incubated for overnight at $4{ }^{\circ} \mathrm{C}$ in the presence of first antibody diluted usually $1: 1000$ in TBS. Blots were washed again with TBS and incubated in the presence of second antibody (AP-conjugated anti-mouse antibody developed in rabbit, Sigma Immuno-Chemicals) for $1 \mathrm{~h}$ at room temperature. After final washes in TBS and TTBS (TBS containing 0.5\% Tween 20) blots were developed by freshly prepared NBT-BCIP (5-Bromo-4-Chloro-3-Indolyl Phosphate/Nitro Blue Tetrazolium, Sigma) as substrate. Molecular masses were determined using the low range (and sometimes by the broad range) prestained standards of Bio-Rad.

Glycosylation was examined on blots of cuticle extracts using HRP-conjugated Wheat Germ Agglutinin (Sigma) for N-acetyl glucosamine (chitin) with a modification of Hawkes' protocol [13].

\section{Immunohistochemistry}

Animals were fixed in $2 \%$ of paraformaldehyde in $0.1 \mathrm{M}$ cacodylate buffer for $4 \mathrm{~h}$ at $4{ }^{\circ} \mathrm{C}$, or in Bouin fixative for $6 \mathrm{~h}$ at room temperature. Fixatives were injected into the body cavity and than the animals were immersed into a large volume of the fixative. After $2 \mathrm{~h}$, the partly fixed body was cut into three pieces and fixed further. Fixed materials were embedded in Paraplast (Dulbeco). Five $\mu \mathrm{m}$ serial sections were cut, placed on poly-L-lysine-coated slides and dried overnight at $39^{\circ} \mathrm{C}$.

After rehydration and blocking (5\% Carnation non-fat dry milk powder in PBS) sections were incubated overnight at $4{ }^{\circ} \mathrm{C}$ in the first antibody diluted $1: 50$. After washing alkaline-phosphatase conjugated rabbit anti-mouse antibody (Sigma Immunochemicals) was applied in $1: 100$ dilution for $1 \mathrm{~h}$ at room temperature. NAMP-Fast-Red tablet sets (Sigma Fast, Sigma Chemical Co.) were used for development. Some sections were incubated in the presence of non-immune mouse serum. These sections remained absolutely negative in each case.

Slides were mounted in Mowiol and photographs were taken on Kodak Gold 100 ASA film with Zeiss Axioskop (Germany, MC80 Microscope Camera).

Due to the aldehyde fixation a pale green autofluorescence emission was observed using violet blue excitation on the non-labelled cells and tissue components [11], while the Fast Red positive structures were brillant purple under these conditions. We found that the UV microscopy gave a much better picture and much more higher resolution to analyse the Fast Red developed sections than the common red-and-white pictures using the simple visible enlighting. 


\section{Hormone treatments}

20-hydroxyecdysone (Sigma) and ecdysteriod agonist RH-5849 (kindly given by Prof. S.E. Reynolds) were injected $(10 \mu \mathrm{g})$ in $10 \mathrm{ml}$ of ethanol into the dorsal part of thoracal segments using a Hamilton syringe with fixed 28 swg needle. Control animals were given $10 \mu \mathrm{l}$ of ethanol alone.

\section{RESULTS}

\section{Isolation of cuticular protein and its distribution detected by Western blots}

Cuticle proteins of the larvae on the 4th day of the last larval stage were electroeluted from $10 \%$ polyacrylamide gel in a preparative chamber. The $33.1 \mathrm{kDa}$ protein (Manduca sexta cuticular protein, MsCP33.1) appeared in the form of a single band in fractions 346-356. Polyclonal antibodies developed against the MsCP33.1 protein reacted specifically with one, single band, with the corresponding molecular mass of the originally isolated antigen on Western blots of total homogenate of the larval cuticle (Fig. 1). The antibody developed against MsCP33.1 recognised the originally isolated protein on Western blots in integumental epidermis on the 1-4 days (Fig. 2). It means that this protein was present in the epidermis during the feeding period and it disappeared from the epidermal cell layer at the beginning of the wandering period. MsCP33.1 protein was present on the 1-7 days of the last larval stage in the cuticle (Fig. 3). In prepupal period, as soon as the apolysis was progressing this protein disappeared from the cuticle. In the freshly moulted (green) pupae when the formation of pupal endocuticle occurs it was detectable again in the samples made from the presumptive wing (Fig. 2). At the end of the pupal stage it was present first of all in the imaginal wing cuticle but it was detectable in the low quantity in the samples made from the integumental cuticle of the non-hatched imago. Any other tissues (hemolymph, fat body, midgut, salivary glands, gonads) of the larval, pupal or imaginal organism were negative on Western blots (Fig. 1).

\section{Effect of 20-hydroxyecdysone treatment on synthesis and secretion of $M s C P 33.1$}

Larvae were injected with 20-hydroxyecdysone after 2-3 hours to the last larval-larval moult. Eight hours later a drastic decrease in amount of MsCP33.1 protein was observed in the epidermis of treated animals (Fig. 4).

In the second experiment the larvae were treated with 20-hydroxyecdysone 24 or 48 hours after the last larval moult. Eight hours later to the injection the amount of MsCP33.1 decreased in epidermal samples on Western blots (Fig. 4). 


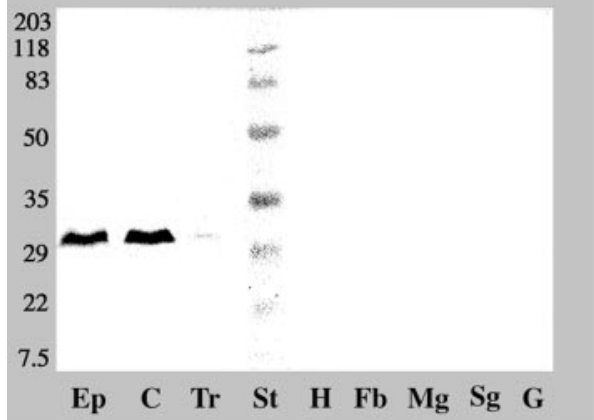

Fig. 1. Antisera against to MsCP33.1 recognized the protein in the homogenate of epidermis, cuticle and trachea on the second day of the last larval stage. Samples of the other tissues did not show any positive reaction. Abbreviations in Fig. 1-Fig. 5: epidermis $\mathrm{Ep}$; cuticle $\mathrm{C}$; trachea, $\mathrm{Tr}$; hemolymph, $\mathrm{H}$; fat body, $\mathrm{Fb}$; midgut, $\mathrm{Mg}$; salivary gland, $\mathrm{Sg}$; gonad, $\mathrm{G}$; BioRad broad range prestained molecular weight standard, St

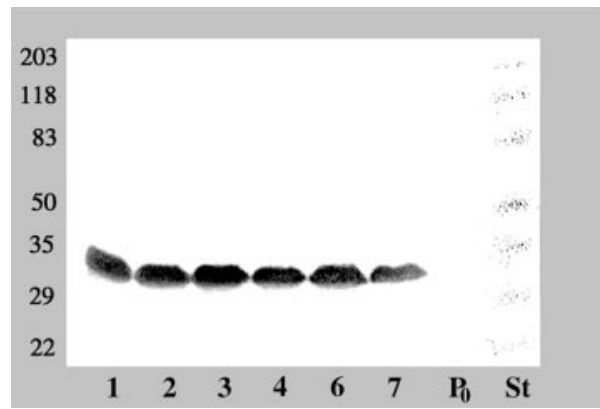

Fig. 3. Immunoblot developed by the antiserum against MsCP33.1 demonstrated that the protein was present continuously in the cuticular samples from the beginning (1:day 1$)$ of the last larval period till the larval/pupal moult (7:day 7). The presence of MsCP33.1 was not detectable on the immunoblots in the samples made from the freshly moulted pupal epidermis and cuticle $\left(\mathrm{P}_{0}\right)$ covering the body surface

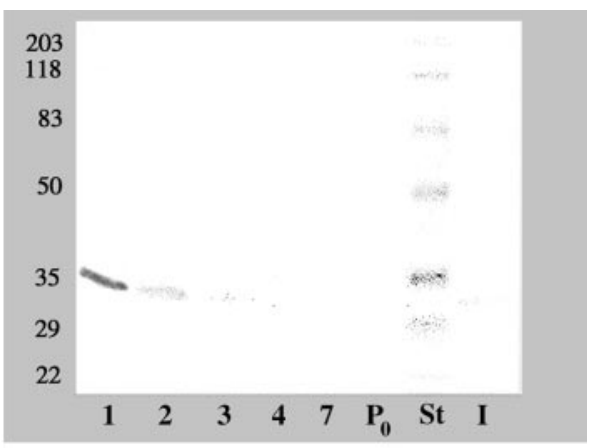

Fig. 2. Immunological evidence for the presence of MsCP33.1 in the samples of epidermis during the feeding period (days 1-4). From the beginning of the wandering period (days 4-7) to the pupal moult $\left(\mathrm{P}_{0}\right)$ this protein disappeared from the epidermal layer, but it reappeared in the imaginal integument (I)

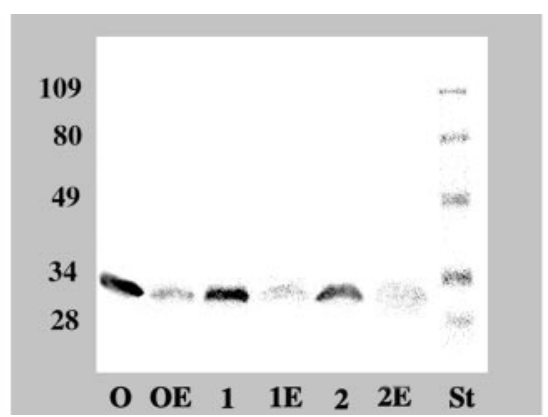

Fig. 4. Western blot analysis of epidermal samples prepared from 20-hydroxyecdysone treated larvae confirmed that the synthesis of MsCP33.1 is negatively regulated by the hormone. The administration was applied after 2-3 hours to the last larval-larval moult. Eight hours later a strong decrease in amount of MsCP33.1 protein was observed in the homogenates of the epidermis of treated animals $(0 \mathrm{E})$ related to sample made from the Ringer-treated larvae (0). If the larvae were treated 24 hours after to the last larval-larval moult the results showed strong similarity to the previous observations (1 and E1). If the larvae were treated 48 hours after to the last larval-larval moult and the samples from the epidermis were prepared 8 hours later, the observed results were the same as in the previous experiments (2 and E2) 


\section{Investigation of chitin-bounding of the MsCP33.1}

Wheat germ agglutinin for $\mathrm{N}$-acetyl glucosamine reacted strongly with numerous cuticular proteins of whole cuticle extract. In spite of that no band corresponded to molecular mass of MsCP33.1 was found on WGA blots, so this protein did not bound to $\mathrm{N}$-acetyl glucosamine or it has left them during the extraction (Fig. 5).

$\mathrm{MsCP33.1}$

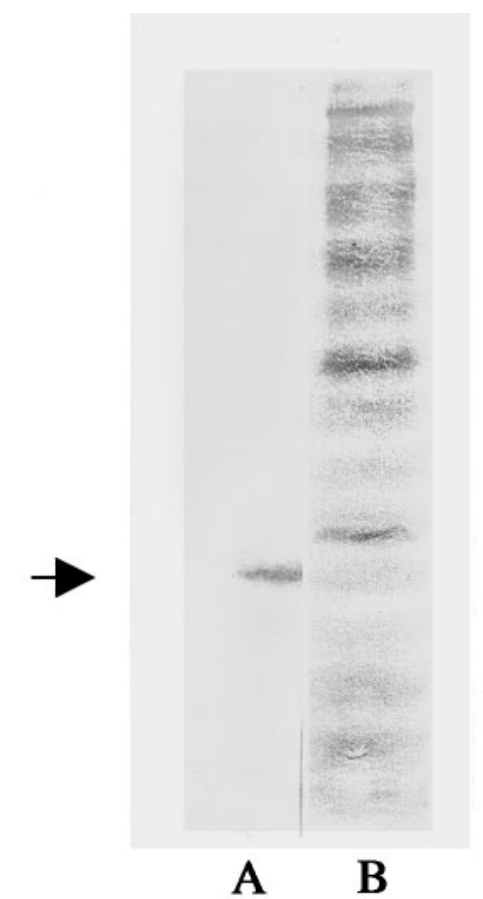

Fig. 5. No corresponding band to molecular mass of MsCP33.1 (A) was found on WGA blots (B), so this protein did not bound to $\mathrm{N}$-acetyl glucosamine or it has left them during the extraction

\section{Immunohistochemical results}

During the feeding period MsCP33.1 was observable at the light microscopical level exclusively in the epidermal cell layer and in the cuticle that lies above the cells. It gave a strong, positive reaction in the cytoplasm of the integumental and tracheal epidermal cells, while all of the other tissues remained negative on the $0-3$ days of last larval stage (Figs 7, 10). From the beginning of the cuticle deposition at the time of the last larval moult it was present in the exo- and endocuticular layers of the integumental cuticle (Fig. 6) both in the intra- and intersegmental areas. Only the so-called assembly zone was devoid of this protein. Presence of MsCP33.1 was also detectable 
Gy. CsiKós et al.

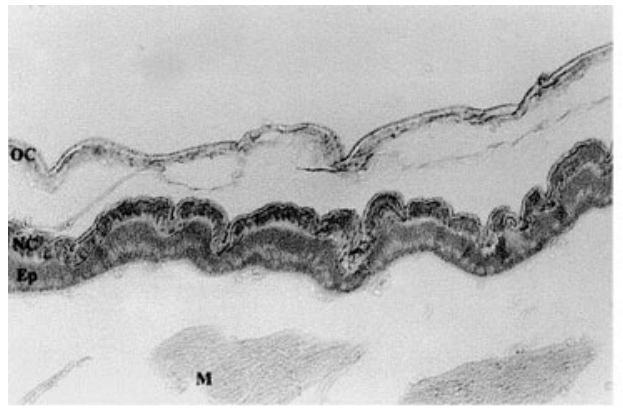

Fig. 6

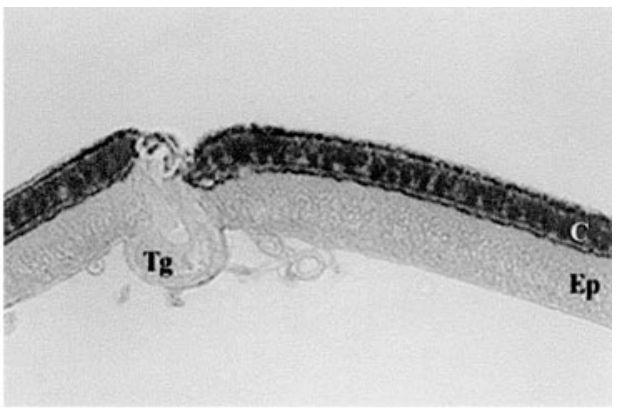

Fig. 7

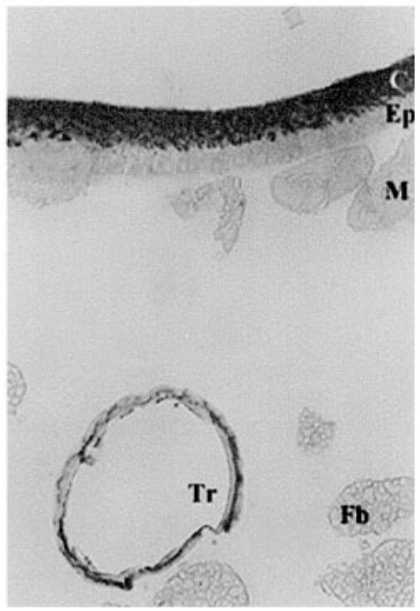

Fig. 8

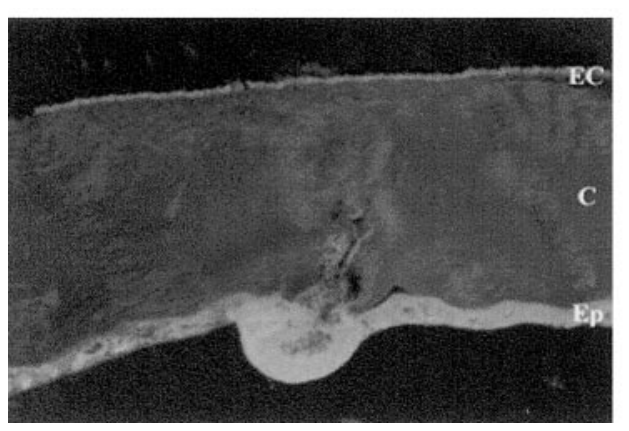

Fig. 9

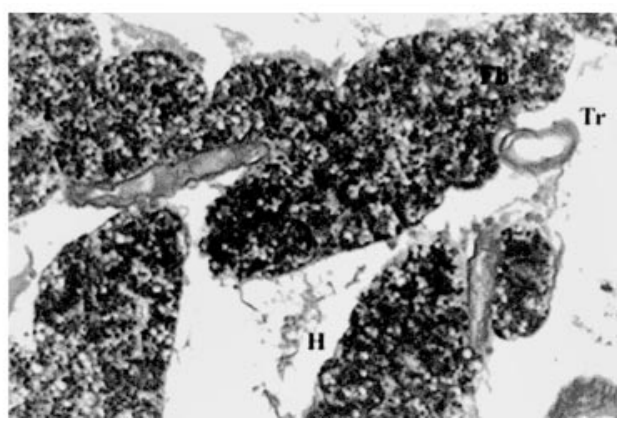

Fig. 10 
in the tracheal cuticle during the last larval period. During the wandering period this protein disappeared from the epidermal cells (Figs 8, 9). As the apolysis of cuticle began, MsCP33.1 seemed to be decomposed since none of the sign of its presence was observed in the exuvial space.

In the freshly moulted (green) pupae when the formation of pupal endocuticle occurs MsCP33.1 was detectable only in the cuticle which was not in contact to the external environment, so in the abdominal cuticle and apodeme as well as in the territory of presumptive wings and legs, too (Figs. $11 \mathrm{~A}-\mathrm{C}$ ). At the time of imaginal moult this protein showed a homogenous distribution in the pupal cuticle. In the longitudinal sections made of the imago before hatching the MsCP33.1 was present only in the continuous cuticle sheet carrying the scales of the wings (Figs. 12B, C) and in the territory of cuticular layer of the apodemes extending into the body cavity (Fig. $12 \mathrm{~A})$.

\section{DISCUSSION}

Insect cuticle is an extracellular structure secreted by the epidermal cell layer consisting of chitin filaments embedded in a protein matrix [1]. This biochemical composition creates the right physiological and structural conditions for it to be in service functionally as both integument and skeleton.

The cuticular proteins make up about half of the weight of the cuticle in the Lepidopteran abdomen [9]. Most insect cuticular proteins are produced and secreted by the underlying epidermal cells $[2,6,8,10,26,36,42]$, but the integumental epidermis is not only source of these proteins. Some of them are transported across the epidermis from the hemolymph $[10,19,25,26,31,33,34,35,39,40]$. Nor is epidermis only concerned with apical secretion to cuticle it occasionally secretes proteins basally into the hemolymph, too [10, 22, 26, 31].

The composition and pattern of structural proteins of the cuticle may be categorized from various points of view. Some of them are present in the cuticle in each developmental stages, but others are definitely stadium-specific proteins $[2,6,8,10$, $12,16,27,36]$. Within a particular stage, different regions of cuticle may contain different proteins $[1,5,9,17,18,21,37,41,44]$, and even different layers in a particular cuticular region may have distinct biochemical composition [22, 24, 43].

Fig. 6. During the last larval/larval moult MsCP33.1 was present in the epidermis (Ep) and equally in the old $(\mathrm{OC})$ and the newly $(\mathrm{NC})$ depositing cuticle. $\times 225$. Abbreviations in Fig. 6-Fig. 12: cuticle, C; epidermis, Ep; epicuticle, EC, fat body, Fb; hemolymph, H; muscle, M; trachea, Tr; trichogen cell, Tg. Figs 7, 8. MsCP33.1 protein was detectable both in the epidermis (Ep) and the cuticle (C) of the integument and tracheae on the first day of the last larval stage. Trichogen cells (Tg), muscles (M) and fat body lobes $(\mathrm{Fb})$ were negatives. $\times 225$. Fig. 9. At the end of the feeding period the MsCP33.1 was translocated and accumulated into the procuticle (C). Presence of MsCP33.1 could not be detected in the epider$\mathrm{mal}(\mathrm{Ep})$ and epicuticular (EC) layer (UV photograph). $\times 225$. Fig. 10. Before the apolysis MsCP33.1 was present in the tracheal cuticle (Tr) but it was not detectable in the fat body lobes $(\mathrm{Fb})$ and hemolymph (H) (UV photograph). $\times 225$ 


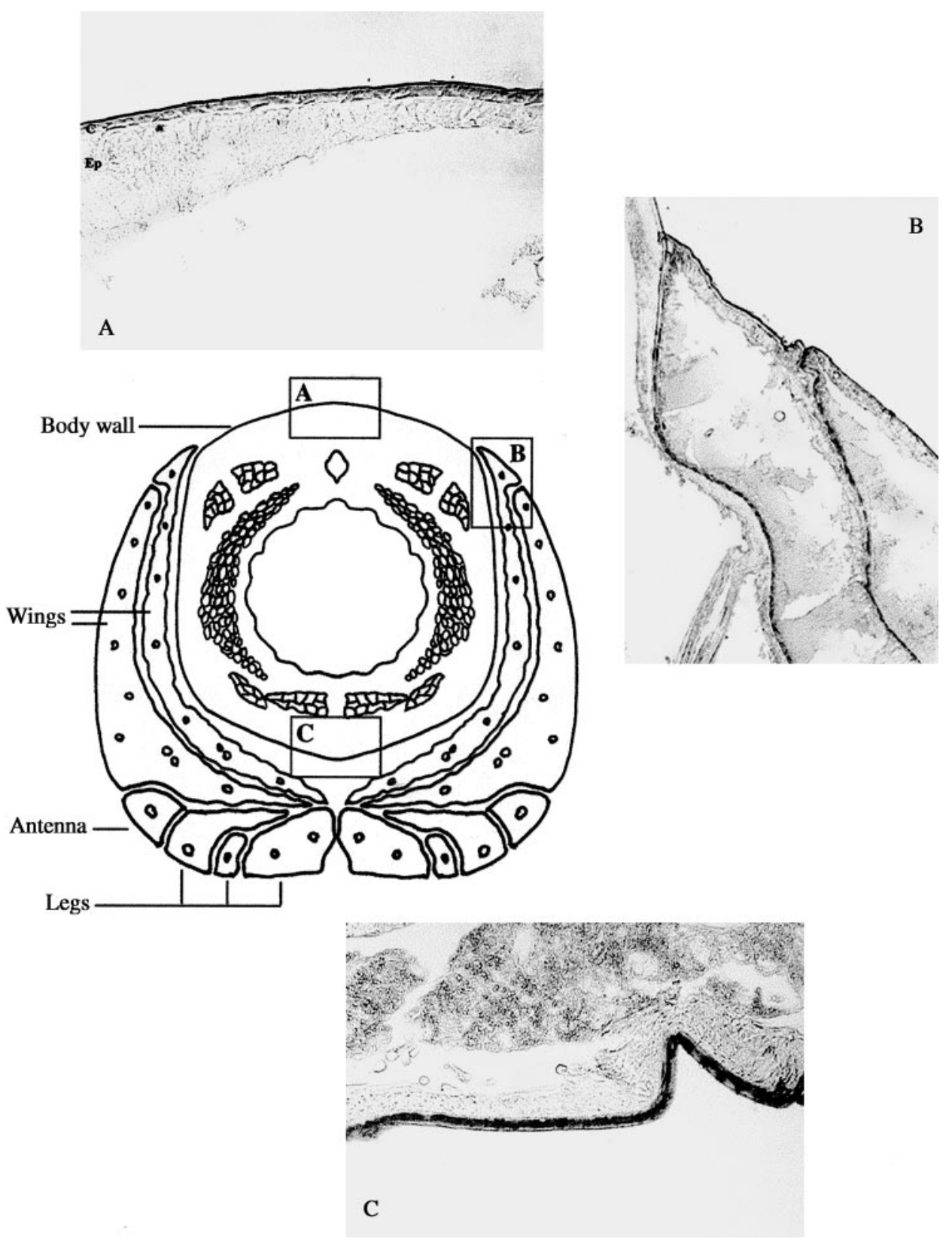

Fig. 11A-C. Antisera developed against the MsCP33.1 cuticular protein gave a strong positive reaction in the cuticle of the abdominal region and the presumptive wing on the first day of the pupal stage $(B, C)$. while the strongly scelotized cuticle was negative (A). $\times 225$ 

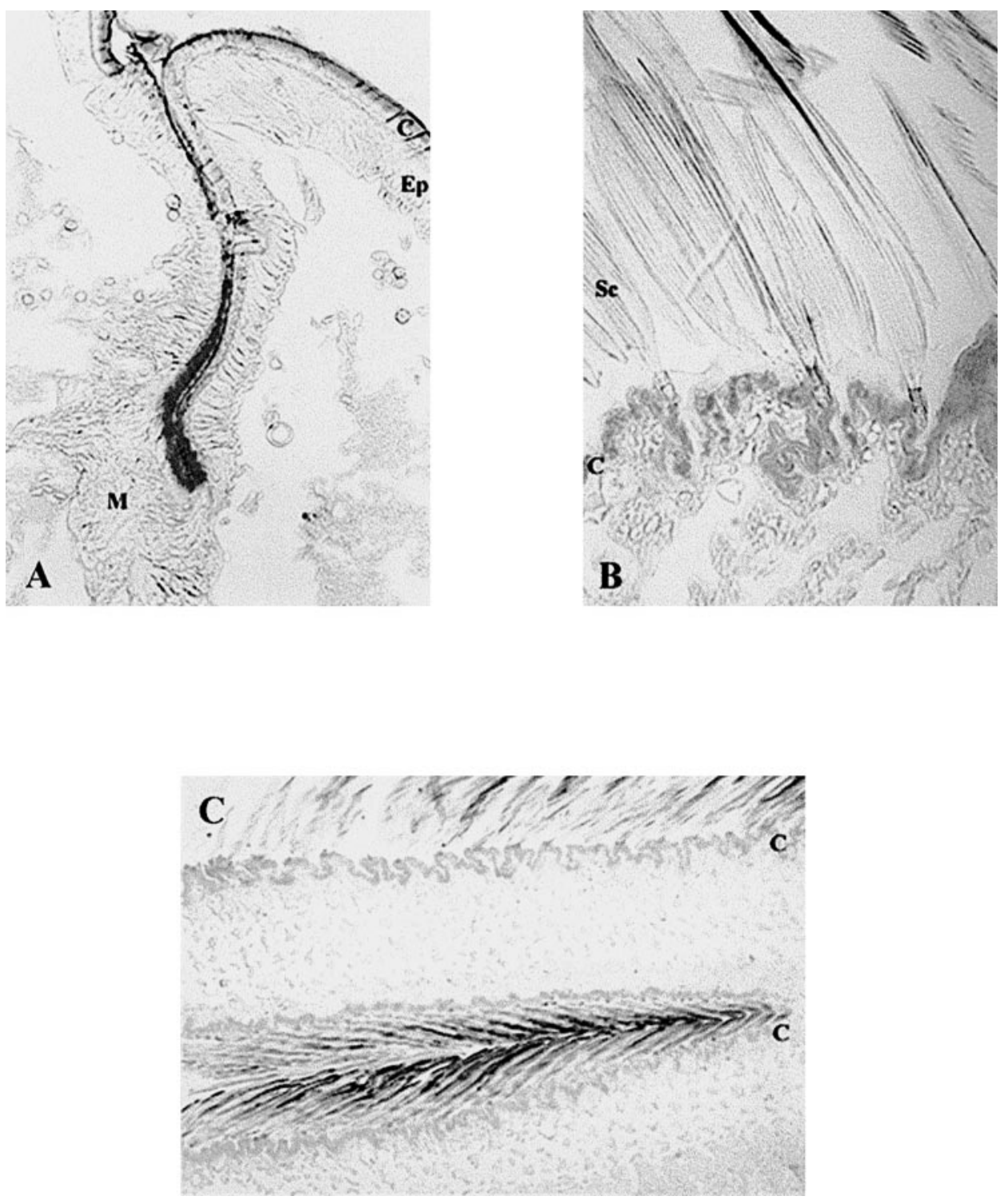

Fig. 12A-C. Before hatching the MsCP33.1 was present exclusively in the territory of apodeme (A) and wing cuticle $(\mathrm{B}, \mathrm{C})$. Muscles $(\mathrm{M})$ and wing scales $(\mathrm{Sc})$ were negatives. $\times 450$ 
Some of the cuticular proteins occur only in the integument, but others are present also in the tracheal cuticle $[10,31]$. Proteins of the cuticle may be assorted on the base of their physiological functions. Beside those ones which are responsible for sustaining the skeletal functions, storage proteins and proteins having role in defence reactions also occur in the cuticle [7, 23, 26, 31].

In our laboratory, in the course of study the proteins of insect cuticle, more than 20 proteins have been isolated from the larval cuticle of Manduca sexta. Isolations were carried out on the 4th day of the last larval stage, i.e. time before the reprogramming of the epidermal cells [28]. At this developmental period the mass of the loosely bound cuticular proteins was large enough to prepare them and their electrophoretic pattern was identical with the data published in literature [16, 18, 44]. Using specific antibodies their fate has been followed by immunological methods during metamorphosis. Fate of four particular proteins, the representative members of the four characteristic groups of cuticular proteins were described in details in a previous study [10].

Recently described MsCP33.1 is a unique protein which differs from all the above-mentioned ones. It occurs solely in the integumental and tracheal epidermis as well as in the integumental and tracheal cuticle. During the postembryonal development presence of MsCP33.1 accompany through at least three stages. It is detectable in the whole cuticle of penultimate and ultimate instar larvae and in the inside of weakly sclerotised parts of early pupal cuticle. Appearance of MsCP33.1 is restricted only the area of the fore- and hindwind as soon as the inner surface of apodemes in the adult stage. In the course of larval periods MsCP33.1 belongs to the group of "classic" cuticular proteins which are synthesized in the epidermal cell [10, 18, 31]. Under the effect of the commitment peak of moulting larvae the synthesis of numerous proteins included cuticular ones ceased [44]. Thus, the synthesis of thees proteins is negatively regulated by 20 -hydroxyecdysone $[2,14,25]$.

The "classic" cuticular proteins disappear from the old, larval cuticle in the course of larval-pupal moult and they do not appear as a component either pupal or imaginal cuticle $[10,18,31]$. Because of MsCP33.1 reappeared in well-defined structures of both pupal and imaginal cuticle according to the results of Western blots and immunohistochemical investigations so it does not suit requirements completely for "classic" cuticular proteins. Recently only some data have been published in the literature suggesting similar developmental pattern. In the Lepidopteran Hyalophora cecropia the epidermal cells synthesize a $12 \mathrm{kD}$ protein (HCCP 12) in the larval stage, its synthesis is ceased before pupal ecdysis, then produce HCCP 12 again when the adult cuticular proteins are produced [4]. The mRNA of a $14.6 \mathrm{kD}$ larval endocuticular protein from Manduca was found throughout the segment in the larva during the intermoult. After the pupal commitment, expression was restricted to the flexible intersegmental regions and occurred only just before pupal and adult ecdysis [29]. While the $14.6 \mathrm{kD}$ cuticular protein seems to be an important component of flexible cuticle, the MsCP33.1 may to be responsible for the hardening of the cuticle. 
Tanning or sclerotization of pharate pupal cuticle is visible in the thorax and abdomen approximately 12-24 h before ecdysis, as evidenced by the appearance of dark brown pigmentation in localized areas of the sclerites. This tanning continued to spread until expansive areas of abdominal and thoracic cuticle and the exoskeleton is totally darkened a few hours later [15]. In the outer part of integument contacting of environment where a massive sclerotization occurs in the cuticle during the first days of pupal stage, the absence of MsCP33.1 was detectable by immunohistochemical methods. At the same time, the inner part of integument covering the pupal legs, the wings and the sternal region contain a relative large quantity of this protein. The appearance of MsCP33.1 in the adults again restricted to the areas which are covered a hard but no strongly sclerotised cuticle. So, it seems probable that the accumulation of this protein give an alternative possibility for the hardening of the integument.

\section{ACKNOWLEDGEMENT}

This work has been supported by the Hungarian Ministry of Education under grant No. FKFP0163/2000, provided to M.S.

\section{REFERENCES}

1. Andersen, S. O., Rafn, K., Krogh, T. N., Hojrup, P., Roepstorff, P. (1995) Comparison of larval and pupal cuticular proteins in Tenebrio molitor. Insect Biochem. Molec. Biol. 25, 177-187.

2. Apple, R. T., Fristrom, J. W. (1991) 20-hydroxyecdysone is required for, and negatively regulates, transcription of Drosophila pupal cuticle protein genes. Dev. Biol. 146, 569-582.

3. Bell, R. A., Joachim, F. G. (1976) Techniques for rearing laboratory colonies of the tobacco hornworm and pink bollworms. Ann. Entomol. Soc. Am. 69, 365-373.

4. Binger, L. C., Willis, J. H. (1990) In vitro translation of epidermal RNA from different anatomical regions metamorphic stages. Insect Biochem. 20, 573-583.

5. Binger, L. S., Willis, J. H. (1994) Identification of the cDNA, gene and promoter for a major protein from flexible cuticles of the giant silkmoth Hyalophora cecropia. Insect Biochem. Molec. Biol. 24, 989-1000.

6. Bouhin, H., Charles, J.-P., Quennedey, B., Delachambre, J. (1992) Developmental profiles of epidermal mRNA content during the development of Bombyx mori larvae. Insect Biochem. 19, 29-39.

7. Brey, T. P., Lee, W. J., Yamakawa, M., Koizumi, Y., Perrot, S., Francois, M., Ashida, M. (1993) Role of the integument in insect immunity: Epicuticular abrasion and induction of cecropin synthesis in cuticular epithelial cells. Proc. Natl. Acad. Sci. USA. 90, 6275-6279.

8. Charles, J.-P., Bouhin, H., Quennedey, B., Current, A., Delachambre, J. (1992) CDNA cloning and deduced amino acid sequence of a major, glycine-rich cuticular protein from the coleopteran Tenebrio molitor. Temporal and spatial distribution of the transcript during metamorphosis. Eur. J. Biochem. 206, 813-819.

9. Cox, D. C., Willis, J. H. (1985) The cuticular proteins of Hyalophora cecropia from different anatomical regions and metamorphotic stages. Insect Biochem. 146, 349-362.

10. Csikós, Gy., Molnár, K., Borhegyi, H. N., Talián, Cs. G., Sass, M. (1999) Insect cuticle, an in vivo model of protein trafficking. J. Cell Science 112, 2113-2124.

11. Del Castillo, P., Llorente, A. R., Stockert, J. C. (1989) Influence of fixation, axciting light and section thickness on the primary fluorescence of samples for microfluorometric analysis. Basic Appl. Histochem. 33, 251-257. 
12. Fechtel, K., Fristrom, D. K., Fristrom, J. W. (1989) Prepupal differentiation in Drosophila: distinct cell types elaborate a shared structure, the pupal cuticle, but accumulate transcriptsin unique patterns. Development 106, 649-656.

13. Hawkes, R. (1982) Identification of Concanavalin A binding sites after sodium dodecyl sulphate-gel electrophoresis and protein blotting. Anal. Biochem. 123, 143-146.

14. Hiruma, K., Hardie, J., Riddiford, L. M. (1991) Hormonal regulation of epidermal metamorphosis in vitro, control of expression of a larval-specific cuticle gene. Dev. Biol. 144, 369-378.

15. Hopkins, T. L., Krchma, L. J., Ahmad, S. A., Kramer, K. J. (2000) Pupal cuticle of Manduca sexta: characterization and profiles during sclerotization. Insect Biochem. Mol. Biol. 30, $19-27$.

16. Horodyski, F. M., Riddiford, L. M. (1989) Expression and hormonal control of a new larval cuticular multigene family at the onset of metamorphosis of the tobacco hornworm. Dev. Biol. 132, 292-303.

17. Jensen, U. G., Rothman, A., Skou, L., Andersen, S. O., Roepstorff, P., Hojrup, P. (1997) Cuticular proteins from the giant cockroach, Blaberus cranifer. Insect Biochem. Molec. Biol. 27, 109-120.

18. Kiely, M. L., Riddiford, L. M. (1985) Temporal programming of epidermal cell protein synthesis during the larval-pupal transformation of Manduca sexta. Roux's Arch. Dev. Biol. 194, 325-335.

19. Koeppe, J. K., Gilbert, L. I. (1973) Immunochemical evidence for the transport of hemolymph protein into the cuticle of Manduca sexta. J. Insect Phys. 19, 615-624.

20. Laemmli, U. K. (1970) Cleavage of structural proteins during the assembly of the head of bacteriophage T4. Nature, 227, 680-685.

21. Lampe, J. D., Willis, J. H. (1994) Characterization of a cDNA and gene encoding a cuticular protein from rigid cuticles of the giant silkmoth Hyalophora cecropia. Insect Biochem. Molec. Biol. 24, 419-435.

22. Locke, M., Kiss, A., Sass, M. (1994) The cuticular localization of integument peptides from particular routing categories. Tissue Cell 26, 707-734.

23. Marmaras, V. J., Charalambidis, N. D., Zervas, Ch. G. (1996) Immune response in insects: the role of phenoloxydase in defense reactions in relation to melanization and sclerotization. Arch. Insect Biochem. Phys. 31, 119-133.

24. Missios, S., Davidson, H. C., Linder, D., Mortimer, L., Okobi, A. O., Doctor, J. S. (2000) Characterization of cuticular proteins in the red flour beetle, Tribolium castaneum. Insect Biochem. Mol. Biol. 30, 47-56.

25. Nakato, H., Izumi, S., Tamino, S. (1992) Structure and expression of gene coding for a pupal cuticle protein of Bombyx mori. Biochem, Biophys. Acta 1132, 161-167.

26. Palli, S. R., Locke, M. (1987) The synthesis of hemolymph proteins by the larval epidermis of an insect Calpodes ethlius (Lepidoptera: hesperidae). Insect Biochem. 17, 711-722.

27. Rebers, J., Riddiford, L. M. (1988) Structure and expression of a Manduca sexta larval cuticle gene homologous to Drosophila cuticle genes. J. Mol. Biol. 203, 411-423.

28. Riddiford, L. M. (1978) Ecdysone-induced change in cellular commitment of the epidermis of the tobacco hornworm Manduca sexta, at the initiation of metamorphosis. Gen. Comp. Endocrinol. 34, 438-446.

29. Riddiford, L. M., Baeckmann, A., Hice, R. H., Rebers, J. (1986) Developmental expression of three genes for larval cuticular proteins of the tobacco hornworm, Manduca sexta. Dev. Biol. 118, 82-94.

30. Samuels, R. I., Reynolds, S. E. (1993) Moulting fluid enzymes of the tobacco hornworm, Manduca sexta: timing of proteolytic and chinolytic activity in relation to pre-ecdysial development. Arch. Insect Phys. Biochem. 24, 33-44.

31. Sass, M., Kiss, A., Locke, M. (1993) Classes of integument peptides. Insect Biochem. Molec. Biol. $23,845-857$.

32. Sass, M., Kiss, A., Locke, M. (1994) The localization of surface integument peptides in tracheae and tracheoles. J. Insect Phys. 40, 561-575.

33. Sass, M., Kiss, Á., Locke, M. (1994) Integument and hemocyte peptides. J. Insect Physiol. 40, 407-421. 
34. Sass, M., Löw, P., Móricz, Zs., Csikós, G., Kovács, J. (1991) The fate and possible role of arylphoryn during the metamorphosis of Mamestra brassicae. Acta Biol. Hung. 42, 141-160.

35. Schenkel, H., Scheller, K. (1986) Stage and tissue specific expression of the genesencoding Calliphorin, the major larval serum protein of Calliphora vicina. Roux's Archs. Dev. Biol. 195, 290-295.

36. Snyder, M., Hunkapiller, M., Yuen, D., Silvert, D., Fristrom, J., Davidson, N. (1982) Cuticle protein genes in Drosophila. Structure, organization and evolution of four clustered genes. Cell, 29, 1024-1040.

37. Stiles, B., Leopold, R. A. (1990) Cuticle proteins from the Anthonomus grandis abdomen: stage specificity and immunological relatedness. Insect Biochem. 20, 113-125.

38. Towbin, H., Staehelin, T., Gordon, J. (1979) Electrophoretic transfer of proteins from polyacrylamide gels to nitrocellulose sheets: procedure and some applications. Proc. Natl. Acad. Sci. USA 76, 4350-4354.

39. Wielgus, J. J. (1983) Stimulation of intermoult cuticle deposition by a hemolymph trophic factor of the tobacco hornworm, Manduca sexta. Insect Biochem. 13, 313-322.

40. Wielgus, J. J., Caldwell, G. A., Nichols, R. L., White, C. F. (1990) Purification, properties, and titer of hemolymph trophic factor in larvae and pupae of Manduca sexta. Insect Biochem. 20, 65-72.

41. Willis, J. H., Reiger, J. C., DeBrunner, B. A. (1981) The metamorphosis of arthropodin. In: Bhaskaran, G., Friedmann, S., Rodrigez, J. G. (eds) Current topics in insect endocrinology and nutrition. Plenum Press, New York, pp. 26-46.

42. Willis, J. H. (1996) Metamorphosis of the cuticle, its proteins, and their genes. In: Gilbert, L. I., Tate, J. R., Atkinson, B. G. (eds) Metamorphosis: Postembryonic reprogramming of gene expression in amphibian and insect cells. Academic Press, Inc., San Diego, pp. 254-282.

43. Wolfgang, W. J., Fristrom, D., Fristrom, J. W. (1986) The pupal cuticle of Drosophila: differential ultrastructural immunolocalization of cuticle proteins. J. Cell Biol. 102, 306-311.

44. Wolfgang, W. J., Riddiford, L. M. (1986) Larval cuticular morphogenesis in the tobacco hornworm, Manduca sexta, and its hormonal regulation. Dev. Biol. 113, 305-316. 